\title{
Improving the Activity of M-N4 Catalysts for the Oxygen Reduction Reaction by Electrolyte Adsorption
}

Svane, Katrine L.; Reda, Mateusz; Vegge, Tejs; Hansen, Heine A.

Published in:

ChemSusChem

Link to article, DOI:

$10.1002 /$ cssc. 201902443

Publication date:

2019

Document Version

Peer reviewed version

Link back to DTU Orbit

Citation (APA):

Svane, K. L., Reda, M., Vegge, T., \& Hansen, H. A. (2019). Improving the Activity of M-N Catalysts for the Oxygen Reduction Reaction by Electrolyte Adsorption. ChemSusChem, 12(23), 5133-5141.

https://doi.org/10.1002/cssc.201902443

\section{General rights}

Copyright and moral rights for the publications made accessible in the public portal are retained by the authors and/or other copyright owners and it is a condition of accessing publications that users recognise and abide by the legal requirements associated with these rights.

- Users may download and print one copy of any publication from the public portal for the purpose of private study or research.

- You may not further distribute the material or use it for any profit-making activity or commercial gain

- You may freely distribute the URL identifying the publication in the public portal 


\title{
CHEMISTRY \& SUSTAINABILITY CHEMSUSCHEM
}

\author{
ENERGY \& MATERIALS
}

\section{Accepted Article}

Title: Improving the Activity of M-N4 Catalysts for the Oxygen Reduction Reaction by Electrolyte Adsorption

Authors: Katrine Louise Svane, Mateusz Reda, Tejs Vegge, and Heine Anton Hansen

This manuscript has been accepted after peer review and appears as an Accepted Article online prior to editing, proofing, and formal publication of the final Version of Record (VoR). This work is currently citable by using the Digital Object Identifier (DOI) given below. The VoR will be published online in Early View as soon as possible and may be different to this Accepted Article as a result of editing. Readers should obtain the VoR from the journal website shown below when it is published to ensure accuracy of information. The authors are responsible for the content of this Accepted Article.

To be cited as: ChemSusChem 10.1002/cssc.201902443

Link to VoR: http://dx.doi.org/10.1002/cssc.201902443 


\title{
Improving the Activity of $\mathrm{M}-\mathrm{N}_{4}$ Catalysts for the Oxygen Reduction Reaction by Electrolyte Adsorption
}

\author{
Katrine L. Svane* Mateusz Reda Tejs VegGe \\ Heine A. HANSEN ${ }^{\dagger}$ \\ Department of Energy Conversion and Storage, \\ Technical University of Denmark, Kgs. Lyngby, Denmark
}

October 11, 2019

\begin{abstract}
Metal and nitrogen co-doped carbons (M-N/Cs) have emerged as promising alternatives to platinum-based catalysts for the oxygen reduction reaction (ORR). Here, density functional theory calculations are used to investigate the adsorption of anions and impurities from the electrolyte on the active site, modelled as an ${\mathrm{M}-\mathrm{N}_{4}}$ motif embedded in a planar carbon sheet $(\mathrm{M}=\mathrm{Cr}, \mathrm{Mn}, \mathrm{Fe}, \mathrm{Co})$. The two-dimensional catalyst structure implies that each metal atom has two potential active sites, one on each side of the sheet. Adsorption of anions or impurities on both sites results in poisoning, but adsorption on one of the sites leads to a modified ORR activity on the remaining site. The calculated adsorption energies show that a number of species adsorb on one of the two sites only under realistic experimental conditions. A few of these adsorbates furthermore modify the adsorption energies of the ORR intermediates on the remaining site in such a way that the limiting potential is improved.
\end{abstract}

\section{Introduction}

Proton exchange membrane fuel cells (PEMFCs) convert the chemical energy stored in $\mathrm{H}_{2}$ to electricity. Water is the only on-site waste product, and the technology is therefore an attractive alternative to the use of fossil fuels, in particular for transportation. 1 The oxygen reduction reaction (ORR) taking place at the cathode is however kinetically slow, even when expensive Pt-based catalysts are used. Thus, extensive research has aimed to identify effective catalysts based on cheap and earth-abundant materials. .24

In this regard pyrolysed carbon materials doped with nitrogen and metal atoms (M-N/Cs) represent an interesting class of materials. These materials were originally inspired by Jasinski's work, demonstrating that phthalocyanines (PC's) are catalytically active for ORR, 5 and the later finding that pyrolysis of the molecules resulted in improved stability ${ }^{[6]}$ Since then similar procedures involving heat-treatment of various organic and organo-metallic precursors have led to a range of different $\mathrm{M}-\mathrm{N} / \mathrm{C}$ catalysts. The improved stability after pyrolysis however comes at the cost of a loss of structural information. The detailed structure of the active site in the resulting

*email: kasv@dtu.dk

†email: heih@dtu.dk amorphous material has been widely debated and nitrogen-doped graphene, nitrogen-coordinated metal atoms and carbon-encapsulated nanoparticles have all been suggested as the active structural component. ${ }^{[7] 10}$ These structure types might be representative of different classes of M-N/C catalysts arising from different synthesis procedures but proof of the exclusive existence or activity of one type of site is elusive. In this work we focus on the $\mathrm{M}^{-\mathrm{N}_{4}}$ motif (Figure 1 1 ) which is known to form the active site of macrocycles such as PC's and porphyrins. 11 Several studies have also identified $\mathrm{M}-\mathrm{N}_{4}$ coordination in pyrolysed Fe- and Cobased catalysts and Mössbauer spectroscopy has been used to correlate the presence of different $\mathrm{Fe}-\mathrm{N}_{x} \mathrm{C}_{y}$ motifs with the ORR activity $\frac{12}{15}$ A number of valid candidate structures for the detailed structure of the $\mathrm{M}-\mathrm{N}_{4}$ motif and the surrounding carbon environment (e.g. $\mathrm{M}-\mathrm{N}_{2+2} \mathrm{C}_{4+4}, \mathrm{M}-\mathrm{N}_{4} \mathrm{C}_{10}, \mathrm{M}-\mathrm{N}_{4} \mathrm{C}_{12}$ etc.) have been proposed based on experimental or theoretical considerations. 12116 19] The structural model used for the density functional theory (DFT) calculations in this work (Figure $1 \mathrm{a}-\mathrm{b}$ ) is based on the Fe- $\mathrm{N}_{4} \mathrm{C}_{12}$ motif found to give a good match with XANES spectra in ref. 16.

The two-dimensional structure of the $\mathrm{M}-\mathrm{N}_{4}$ motif is distinct from the three-dimensional structure of typical surface-based catalysts such as Pt nanoparticles. 


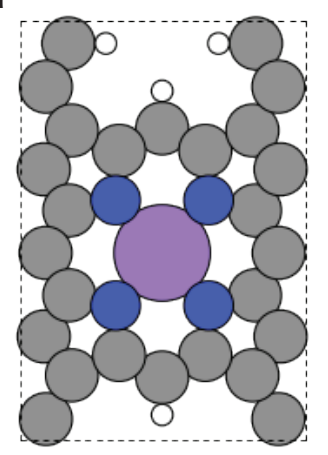

b

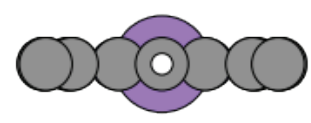

C

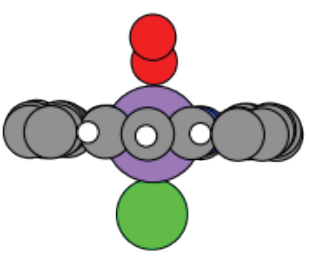

Figure 1: Computational model of the $\mathrm{M}-\mathrm{N}_{4}$ motif in a) top and b) side view. c) Side view with adsorbates on both sides of the metal atom, here $\mathrm{O}_{2}$ adsorption and $\mathrm{Cl}^{-} . \mathrm{Cl}$ is green, $\mathrm{C}$ is grey, $\mathrm{H}$ is white, $\mathrm{N}$ is blue, $\mathrm{O}$ is red and the metal atom is purple.

On the metal surface catalytic sites are close together and it is well known that impurities or anions from the electrolyte can adsorb on the surface and block one or several of these sites, leading to a decrease in activity. 20 22 For M-N/C catalysts the distance between neighbouring $\mathrm{M}-\mathrm{N}_{4}$ motifs is larger but each $\mathrm{M}-\mathrm{N}_{4}$ motif has two potential catalytic sites, one on each side of the $\mathrm{C} / \mathrm{N}$-plane (Figure 1 c). Assuming that the structure is free-standing or sufficiently porous, adsorbates can be present on both of these sites. These adsorbates will be spatially seperated but electronically coupled since the presence of an adsorbate on one side of the metal atom will modify its electronic states, thereby affecting the binding of a second adsorbate on the other side. In the ideal situation ORR would proceed on both sides simultaneously at a low overpotential, but for this to be possible the active sites must be free of other adsorbates and the binding strengths of the reaction intermediates should be neither too strong nor too weak. A more realistic scenario is that one or both of the two sites are blocked by adsorbates that are not part of the ORR. If an adsorbate binds on one side of the $\mathrm{M}-\mathrm{N}_{4}$ motif, the other side is still free for ORR to proceed (Figure 11.). In some cases this can be used to improve the adsorption energies of the ORR intermediates, such that the overpotential is lowered. The resulting increase in catalytic rate can then compensate for the reduced number of catalytic sites available, and can lead to an overall increase in activity. The presence of a ligand on one side of the active side has been indicated by experiments, $\underline{16[23}$ and several theoretical reports have investigated the

effect of spontaneously evolved ORR intermediates as well as $\mathrm{CN}^{-}$, pyridine, $\mathrm{Cl}^{-}, \mathrm{NH}_{2}$ and $\mathrm{NH}_{3}$ on the ORR activity. 15/17/24 31 More recently, the effect of anions from the electrolyte was considered, and calculated adsorption energies were shown to correlate with the experimentally observed increase in ORR activity for an Fe-N/C catalyst in $\mathrm{H}_{3} \mathrm{PO}_{4}$ and $\mathrm{CH}_{3} \mathrm{COOH}$ solutions. 3233

The potentially beneficial presence of an adsorbate on one side of the $\mathrm{M}-\mathrm{N}_{4}$ motif is closely related to the detrimental poisoning of the catalyst, where adsorbates block both sides of the metal atom, leading to a loss of catalytic activity. Poisoning of $\mathrm{M}-\mathrm{N} / \mathrm{C}$ catalysts has been studied experimentally for a number of potential poisons, including halide ions, $\mathrm{F}_{2}, \mathrm{NCS}^{-}, \mathrm{H}_{2} \mathrm{~S}, \mathrm{CN}^{-}$, $\mathrm{CO}, \mathrm{NO}_{x}$ and $\mathrm{H}_{3} \mathrm{PO}_{4} \cdot 34$ As an example, Wang et al. studied the influence of various anions and small molecules on a Fe-N/C catalyst and found that the activity was unaffected by $\mathrm{CO}$ and $\mathrm{NO}_{x}$, but would be slightly suppressed by the presence of halide ions and more significantly suppressed by $\mathrm{NCS}^{-}, \mathrm{H}_{2} \mathrm{~S}$ and $\mathrm{SO}_{2} \cdot{ }^{34}$ Two other studies of different types of Fe-N/C catalysts however saw no effect of $\mathrm{F}^{-}$and $\mathrm{NCS}^{-}, 35$ but a partial decrease in activity upon exposure to $\mathrm{CO} .36$ Such variation in the obtained results probably arises as a result of differences in the poisoning procedure as well as differences in the catalyst preparation schemes, and thereby in the detailed structure of the active site. Indeed, density functional theory (DFT) calculations have shown that different types of $\mathrm{Fe}-\mathrm{N}_{x} \mathrm{C}$ sites behave differently towards the adsorption of $\mathrm{CO} .36$

It is clear from the above discussion that an understanding of the adsorption properties of common anions and impurities is important in order to optimize the performance of $\mathrm{M}-\mathrm{N} / \mathrm{C}$ catalysts and avoid poisoning. We therefore use DFT to systematically calculate the effect of various adsorbates on the $\mathrm{M}-\mathrm{N}_{4}$ catalysts with $\mathrm{M}=\mathrm{Cr}, \mathrm{Mn}, \mathrm{Fe}, \mathrm{Co}$. These four metals are chosen from the relatively cheap and abundant $3 d$ metals because the limiting potentials of the bare catalysts are already good (c.f. the electronic supplementary information (ESI), Section S1), such that the shift produced by an adsorbate, expected to be $<1 \mathrm{eV}$, could lead to a limiting potential close to the optimal value. The list of investigated adsorbates $\left(\mathrm{A}^{n-}\right.$ where $n=0,1,2)$ in Table 1 contains a number of anions from common acids, in addition to the gases $\mathrm{NO}$ and $\mathrm{CO}$ which are considered poisonous to platinum based ORR catalysts. Firstly, the adsorption energies of one and two adsorbates on the central metal atom are calculated and compared with the adsorption energies 
Table 1: List of acids and molecules considered in this work, the $\mathrm{pK}_{a}$ (for acids), the corresponding adsorbate $\left(\mathrm{A}^{n-}\right)$ considered and any competing species other than $\mathrm{H}_{2} \mathrm{O}$ and $\mathrm{OH}^{-}$relevant at $\mathrm{pH}=0.3(0.5 \mathrm{M}$ strong acid $)$.

\begin{tabular}{|c|c|c|c|}
\hline Acid/molecule & $\mathrm{pK}_{a}$ & $\mathrm{~A}^{n-}$ & Competing speci \\
\hline$\overline{\mathrm{HCl}}$ & $<0$ & $\mathrm{Cl}^{-}$ & - \\
\hline $\mathrm{HClO}_{4}$ & $<0$ & $\mathrm{ClO}_{4}{ }^{-}$ & - \\
\hline $\mathrm{H}_{2} \mathrm{SO}_{4}$ & $<0$ & $\mathrm{HSO}_{4}{ }^{-}$ & $\mathrm{SO}_{4}{ }^{2-}$ \\
\hline HNCS & $<0$ & $\mathrm{NCS}^{-}, \mathrm{SCN}^{-}$ & \\
\hline $\mathrm{H}_{3} \mathrm{PO}_{4}$ & 2.16 & $\mathrm{H}_{2} \mathrm{PO}_{4}^{-}$ & $\mathrm{H}_{3} \mathrm{PO}_{4}, \mathrm{HPO}_{4}{ }^{2-}$ \\
\hline $\mathrm{HF}$ & 3.20 & $\mathrm{~F}^{-}$ & \\
\hline $\mathrm{HNO}_{2}$ & 3.25 & $\mathrm{NO}_{2}{ }^{-}$ & $\mathrm{NO}$ \\
\hline $\mathrm{HCOOH}$ & 3.75 & $\mathrm{HCOO}^{-}$ & $\mathrm{HCOOH}$ \\
\hline $\mathrm{HCN}$ & 9.21 & $\mathrm{CN}^{-}$ & $\mathrm{HCN}$ \\
\hline $\mathrm{NO}$ & - & $\mathrm{NO}$ & $\mathrm{NO}_{2}{ }^{-}$ \\
\hline $\mathrm{CO}$ & - & $\mathrm{CO}$ & - \\
\hline $\mathrm{H}_{2} \mathrm{O}$ & 14 & $\mathrm{OH}^{-}$ & $\mathrm{H}_{2} \mathrm{O}, \mathrm{O}$ \\
\hline
\end{tabular}

of $\mathrm{H}_{2} \mathrm{O}, \mathrm{OH}^{-}, \mathrm{O}$ and the competing species listed in Table 1. The results are used to determine if adsorption on one side only is possible at realistic potentials and adsorbate concentrations. We then continue to investigate how an adsorbate on one side of the metal atom affects the binding of the ORR intermediates. Finally, these results are used to identify a number of combinations of metal atom and adsorbate that will lead to an improvement in the limiting potential for ORR relative to the bare catalyst.

\section{Computational Methods}

Spin-polarised density functional theory calculations 4 were performed using the Vienna ab initio simulation package (VASP) ${ }^{43}$ and projector augmented wave $(\mathrm{PAW})^{44}$ pseudupotentials. The atomic simulation environment (ASE) ${ }^{45}$ was used to set up and analyse the calculations. The exchange and correlation energy was described using the BEEF-vdW functional in order to include the effects of dispersive interactions. ${ }^{46]}$ A plane-wave cutoff of $600 \mathrm{eV}$ was used and the structures were relaxed until all forces were below $0.01 \mathrm{eV} \AA^{-1}$.

The active site is modelled as in ref. 32 with an $\mathrm{M}-\mathrm{N}_{4}$ motif embedded in a planar carbon structure (Figure 1a-b), such that the unit cell contains 26 carbon atoms. The unit cell dimensions in the plane of the catalyst are ca. $8.2 \times 12.4 \AA$ with small variations for the different metal atoms. The dimension perpendicular to the catalyst is adjusted such that there is a minimum of $8 \AA$ of vacuum between the adsorbates on different sides of the catalyst across the periodic boundary and a minimum of $14 \AA$ between periodic images of the carbon sheet, and a dipole correction is used to decouple the electrostatic potentials. The Brillouin zone is sampled with a $(4 \times 3 \times 1)$ MonkhorstPack $k$-point mesh. With these computational settings adsorption energies are converged within $0.01 \mathrm{eV}$, but the size of the graphene sheet encapsulating the active site can lead to larger variations in the binding energies of ca. $0.10 \mathrm{eV}$ (c.f. section S2 in the ESI). We furthermore note that our results may not be representative of all types of active sites found in M-N/C catalysts. Previous studies have shown that adsorption energies for different models of the $\mathrm{M}-\mathrm{N}_{4}$ site (e.g. $\mathrm{M}-\mathrm{N}_{4} \mathrm{C}_{10}$, $\mathrm{M}-\mathrm{N}_{4} \mathrm{C}_{12}$ ) can differ by more than $0.50 \mathrm{eV}$ but that trends are often similar. $36 / 47$

Solvent effects on the surface and adsorbates are included using the implicit solvent model implemented in VASPsol with a dielectric constant of $80 . \frac{48149}{}$ Since explicit water molecules are not included in our model, hydrogen bonds between the adsorbate and the solvent are not taken into account which could affect the calculated adsorption energies. Tests performed for $\mathrm{Fe}-\mathrm{N}_{4}$ in the ESI of ref. 32 however suggest that the effect is relatively small, as an example the difference in adsorption free energy of $\mathrm{OH}^{-}$with implicit and explicit solvent was found to be $0.03 \mathrm{eV}$.

The change in adsorption energy with an applied potential is calculated using the computational hydrogen electrode (CHE), ${ }_{50}^{50}$ i.e. the Gibbs free energy of the reaction at a potential $U_{\mathrm{vs}} \mathrm{RHE}$ is:

$$
\Delta \mathrm{G}_{\mathrm{CHE}}\left(U_{\mathrm{vs}} \mathrm{RHE}\right)=\Delta \mathrm{G}(\mathrm{U}=0 \mathrm{~V})-n e U_{\mathrm{vs}} \mathrm{RHE}
$$

where $n$ is the number of electrons involved in the reaction and $e$ is the numerical charge of an electron. $\Delta \mathrm{G}(U=0 \mathrm{~V})$ is calculated from DFT and includes the change in electronic energy, as well as changes in zero point energy (ZPE) and vibrational energy and entropy. The two latter terms are included by calculating the vibrational frequencies of the adsorbates in the harmonic approximation and adding the corresponding contributions to the free energy at $298 \mathrm{~K}$. The absence of imaginary frequencies can furthermore be used to verify that the structure is a local minimum. For some adsorbates the energy landscape is very soft and small imaginary frequencies may occur. These are corrected by comparison with similar structures, while structures with larger imaginary frequencies are reoptimised (see the ESI, Section S8 for details).

The adsorption free energy of the adsorbate $\mathrm{A}^{n-}$ ( $n=0,1,2)$ from solution is calculated following the 
thermodynamic cycle shown in Figure 2

$$
\begin{aligned}
\Delta \mathrm{G}_{\text {ads }}\left(\mathrm{A}^{n-}\right)= & \Delta \mathrm{G}_{\mathrm{CHE}}\left(U_{\text {vs RHE }}\right)-\Delta \mathrm{G}_{\text {solv }}\left(\mathrm{H}_{n} \mathrm{~A}(\mathrm{~g})\right) \\
& -\Delta \mathrm{G}_{\text {dilut }}\left(\mathrm{H}_{n} \mathrm{~A}(\text { solvated })\right)
\end{aligned}
$$

where the free energy of solvation, $\Delta \mathrm{G}_{\text {solv }}\left(\mathrm{H}_{n} \mathrm{~A}(\mathrm{~g})\right)$, can be calculated using literature data for the standard formation enthalpies and entropies. The free energy of dilution, $\Delta \mathrm{G}_{\text {dilut }}\left(\mathrm{H}_{n} \mathrm{~A}\right.$ (solvated)), is calulated following the equation:

$$
\Delta \mathrm{G}_{\text {dilut }}\left(\mathrm{H}_{n} \mathrm{~A}(\text { solvated })\right)=R T \log \left(a_{\mathrm{H}^{+}}^{n} a_{\mathrm{A}^{n-}}\right)
$$

where $R$ is the gas constant, $T$ is the temperature and $a_{\mathrm{H}^{+}}$and $a_{\mathrm{A}^{n-}}$ are the activities of $\mathrm{H}^{+}$and $\mathrm{A}^{n-}$ in the diluted solution, which are likewise taken from literature data. A list of the applied values for $\Delta \mathrm{G}_{\text {dilut }}$ $\left(\mathrm{H}_{n} \mathrm{~A}(\right.$ solvated $\left.)\right), \Delta \mathrm{G}_{\text {solv }}\left(\mathrm{H}_{n} \mathrm{~A}(\mathrm{~g})\right)$ and relevant references are given in Section S3 and S4 of the ESI.

For the anions and undissociated acids (except $\left.\mathrm{OH}^{-} / \mathrm{H}_{2} \mathrm{O}\right)$ the adsorption energies are calculated for a $0.5 \mathrm{M}$ solution. To avoid comparing adsorbates at different $\mathrm{pH}$ values it is assumed that the $\mathrm{pH}$ is kept constant by adding another (non-adsorbing) acid to the weak acids with $\mathrm{pK}_{a}>0$, such that $\left[\mathrm{H}^{+}\right]=0.5 \mathrm{M}$ for all adsorbates. The possible choices of non-adsorbing acid will be discussed in the Results and Discussion section. Adsorption of $\mathrm{CO}$ and NO is calculated assuming the solvated gas to be in equilibrium with the gas phase at a partial pressure of 1 bar, such that $\Delta \mathrm{G}_{\text {solv }}$ and $\Delta \mathrm{G}_{\text {dilut }}$ sum to 0 . If the partial pressure of the gas is changed to a different value, $p_{x}$, the free energy is changed following the equation:

$$
\Delta \mathrm{G}\left(p=p_{x}\right)=\Delta \mathrm{G}^{\ominus}+R T \ln \left(\frac{p_{x}}{p_{0}}\right)
$$

The energy of $\mathrm{O}_{2}$ in the gas-phase is poorly described by GGA functionals and is therefore corrected to reproduce the Gibbs free energy of the formation of $\mathrm{H}_{2} \mathrm{O}$. By comparison between DFT reaction energies and experimental data it was found that part of this error is also present in the ${ }^{*} \mathrm{OOH}$ intermediate, while smaller corrections to the energy of $\mathrm{H}_{2} \mathrm{O}$ and $\mathrm{H}_{2}$ further increased the accuracy. ${ }^{51 / 52}$ The corrections specific to the BEEF-vdW functional have been used in this work (c.f. Section S6 of the ESI for details):

$$
\begin{aligned}
& \Delta E(\mathrm{O}-\mathrm{O})=0.20 \mathrm{eV} \\
& \Delta E\left(\mathrm{H}_{2} \mathrm{O}\right)=-0.03 \mathrm{eV} \\
& \Delta E\left(\mathrm{H}_{2}\right)=0.09 \mathrm{eV}
\end{aligned}
$$

\section{Results and Discussion}

\section{Adsorbates on $\mathrm{M}-\mathrm{N}_{4}$ motifs}

Firstly, the adsorption of the adsorbates listed in Table 1 is investigated. The structure of the M-N 4 motif is optimised with an adsorbate $\left(\mathrm{A}^{n-}\right)$ on one side and with $\mathrm{A}^{n-}$ adsorbed on both sides of the metal atom. The adsorption free energy $\left(\Delta \mathrm{G}_{\text {ads }}\left(\mathrm{A}^{n-}\right)\right)$ is calculated following Eqn. 2 and the differential adsorption energy of the second adsorbate $\left(\Delta \mathrm{G}_{\text {ads }}\left(2 \mathrm{~A}^{n-}\right)-\Delta \mathrm{G}_{\text {ads }}\left(\mathrm{A}^{n-}\right)\right)$ is plotted against $\Delta \mathrm{G}_{\text {ads }}\left(\mathrm{A}^{n-}\right)$ in Figure 3 . For the anionic adsorbates the adsorption energy is dependent on the electrode potential through the computational hydrogen electrode (Eqn. 1), while the adsorption energies of the neutral adsorbates are assumed to be unaffected by the potential. 50 Figure 3 is plotted at a potential of $0.75 \mathrm{~V}$ which is a representative value of the potential at which the fuel cell would be operated. Note that the points corresponding to $\mathrm{O}$ are outliers and they have therefore not been included in the plots but data for the adsorption energies and large scale plots can be found in Section S8 and S9 of the ESI.

Since the catalyst is two-dimensional there are three different adsorption scenarios for an adsorbate $\mathrm{A}^{n-}$ :

i) $\mathrm{A}^{n-}$ adsorbs on both sides of the metal atom, leading to poisoning. The regions where this is the case are shaded light grey in Figure 3 .

ii) $\mathrm{A}^{n-}$ adsorbs on one side of the catalyst only, leaving the other side available for ORR. The adsorption of $\mathrm{A}^{n-}$ modifies the electronic states of the metal atom and thereby the binding energies of the ORR intermediates and the limiting potential. Regions where this is the case have a white background in Figure 3 .

iii) $\mathrm{A}^{n-}$ does not adsorb, either because it has a positive free energy of adsorption, or because adsorption of another species in the solution is more favourable. Regions where this is the case are shaded dark grey in Figure 3. To make the figure general for all adsorbates only the competitive adsorption of $\mathrm{H}_{2} \mathrm{O}, \mathrm{OH}^{-}$and $\mathrm{O}$ has been considered in defining the boundaries of these regions. In aqueous solution at $U=0.75 \mathrm{~V}$, in the absence of any other adsorbates, $\mathrm{OH}^{-}$will be adsorbed on both sides of the $\mathrm{Mn}$ catalyst $\left(\Delta \mathrm{G}_{\mathrm{ads}}\left(2 \mathrm{OH}^{-}\right)=-0.43 \mathrm{eV}\right)$. The $\mathrm{Cr}$ and $\mathrm{Fe}$ catalysts will have almost equal adsorption energies for $\mathrm{O}$ and $\mathrm{OH}^{-}$adsorbed on one side; $\left(\Delta \mathrm{G}_{\mathrm{ads}}\left(\mathrm{OH}^{-}\right)=-0.66 \mathrm{eV}, \Delta \mathrm{G}_{\mathrm{ads}}(\mathrm{O})=-0.67 \mathrm{eV}\right.$ on $\mathrm{Cr}$ and $\Delta \mathrm{G}_{\mathrm{ads}}\left(\mathrm{OH}^{-}\right)=\Delta \mathrm{G}_{\mathrm{ads}}(\mathrm{O})=-0.06 \mathrm{eV}$ on $\left.\mathrm{Fe}\right)$, and both situations will therefore be considered as possible in the following. Finally, the Co catalyst will have 


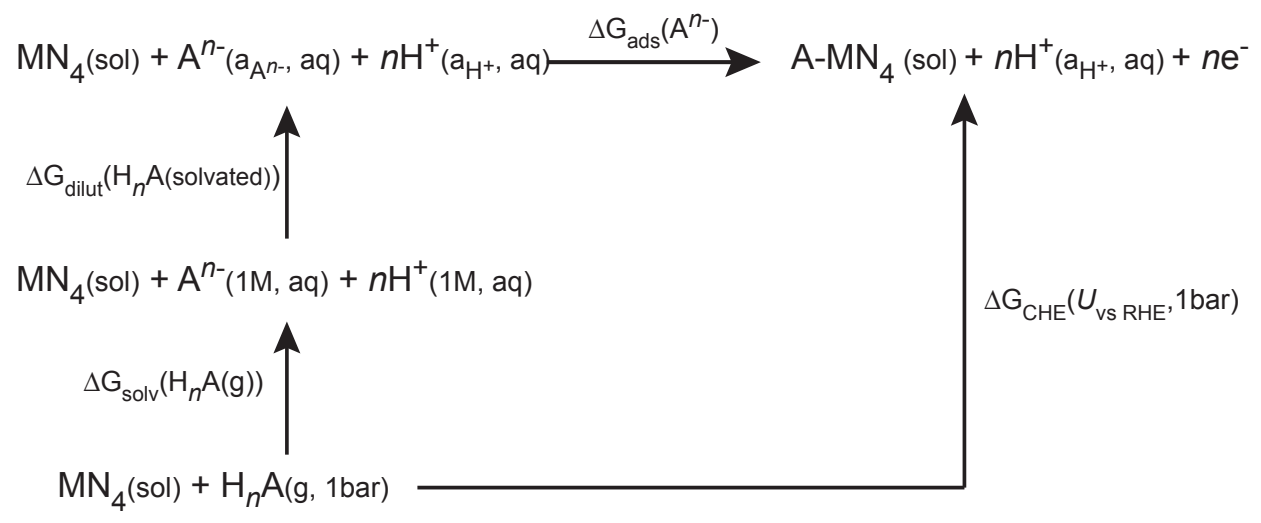

Figure 2: Thermodynamic cycle used to calculate the free energy of adsorption of the anion $\mathrm{A}^{n-}$ from solution.

two $\mathrm{H}_{2} \mathrm{O}$ molecules adsorbed, although the second water molecule is very weakly bound $\left(\Delta \mathrm{G}_{\text {ads }}\left(\mathrm{H}_{2} \mathrm{O}\right)=\right.$ $\left.-0.03 \mathrm{eV}, \Delta \mathrm{G}_{\mathrm{ads}}\left(2 \mathrm{H}_{2} \mathrm{O}\right)=-0.04 \mathrm{eV}\right)$. For another adsorbate to bind instead of $\mathrm{H}_{2} \mathrm{O}, \mathrm{OH}^{-}$or $\mathrm{O}$ it must bind more strongly than these values.

Most of the adsorbates in Figure 3 are located in the grey regions, indicating that they either bind too strongly, leading to poisoning of the catalyst or too weakly, such that the activity remains that of the catalyst with $\mathrm{O}, \mathrm{OH}^{-}$or $\mathrm{H}_{2} \mathrm{O}$ adsorbed. Some trends in the adsorption behaviour can be established, i.e. the binding strength generally increases when the central metal atom is changed through the series $\mathrm{Co}<\mathrm{Fe}<\mathrm{Mn}<\mathrm{Cr}$ and particular adsorbates such as $\mathrm{NO}_{2}{ }^{-}$and $\mathrm{CN}^{-}$are found to be among the strongest binding adsorbates on all four metals, while $\mathrm{ClO}_{4}{ }^{-}$is one of the weakest. However, the subtle energy balance between the scenarios i-iii) makes it difficult to use such trends to make reliable predictions of the number of adsorbates at a given potential.

It is possible to change the free energy of adsorption to some extent, and thereby shift the position of the points in Figure $3 \mathrm{a}$-d. For all acids except $\mathrm{H}_{2} \mathrm{O}$, this can be done by changing the concentration. Following Eqn. 3, the adsorption will be weaker when the concentration is lowered. In the case of the gasses NO and $\mathrm{CO}$, the same effect can be achieved by changing the partial pressure of the gas (Eqn. 4), with a lower pressure resulting in a weaker binding of the adsorbate. In both cases the binding energies of the first and the second adsorbate are affected simultaneously, and points are thus displaced along the diagonal. Arrows in Figure 3 p-d indicate how the points of selected adsorbates are shifted when the concentration or the partial pressure is decreased to $1 \mathrm{mM}$ or $1 \mathrm{mbar}$. For anions, a decrease in potential also leads to shifts in this direction, but for obvious reasons it is undesirable to lower the potential too much or to increase it beyond the limiting potential of the ORR.

The practical range of adsorption energies that can be achieved in this way is limited by the concentrations and pressures that can conveniently be handled experimentally. In particular, a high ionic strength is undesirable, since it reduces the solubility of $\mathrm{O}_{2}$. In the following it is assumed that concentrations are easily adjusted between $1 \mathrm{mM}$ and $1 \mathrm{M}$ for all acids, and the partial pressure of $\mathrm{CO}$ and $\mathrm{NO}$ can be adjusted between 1 bar and 1 mbar. This corresponds to a range of binding energies of $0.18 \mathrm{eV}$ per adsorbate.

As explained in the Methods section, the results presented here are obtained for a $\mathrm{pH}$ value of 0.3 , corresponding to $0.5 \mathrm{M}$ strong acid. For $\mathrm{CO}$ and $\mathrm{NO}$, for weak acids or when the concentration of a strong acid is lowered, the $\mathrm{pH}$ value is assumed to be maintained by addition of another acid which must be non-adsorbing. $\mathrm{HClO}_{4}$ is found to be ideal for this purpose since $\mathrm{ClO}_{4}{ }^{-}$does not adsorb on any of the four metals considered here at potentials below $0.75 \mathrm{~V}$ and concentrations below $0.5 \mathrm{M} \mathrm{HClO}_{4}$.

Figure 3 shows which adsorbates will bind more strongly than $\mathrm{O}, \mathrm{OH}^{-}$and $\mathrm{H}_{2} \mathrm{O}$ but it is also possible that another competing species will bind even stronger. This could be the undissociated form of a weak acid or, in the case of a polyprotic acid, the dianion. Therefore, the adsorption of the competing species listed in Table 1 was investigated. The calculated adsorption ener- 
a

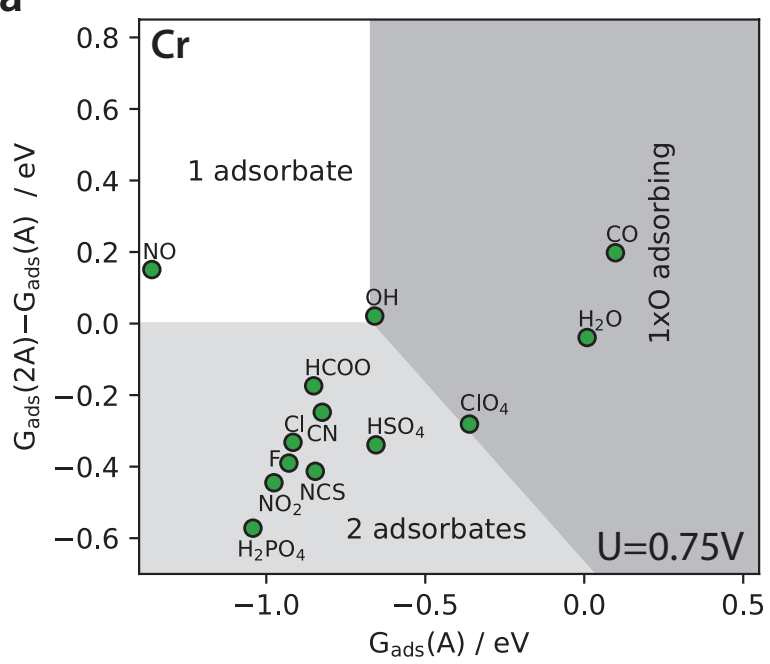

C

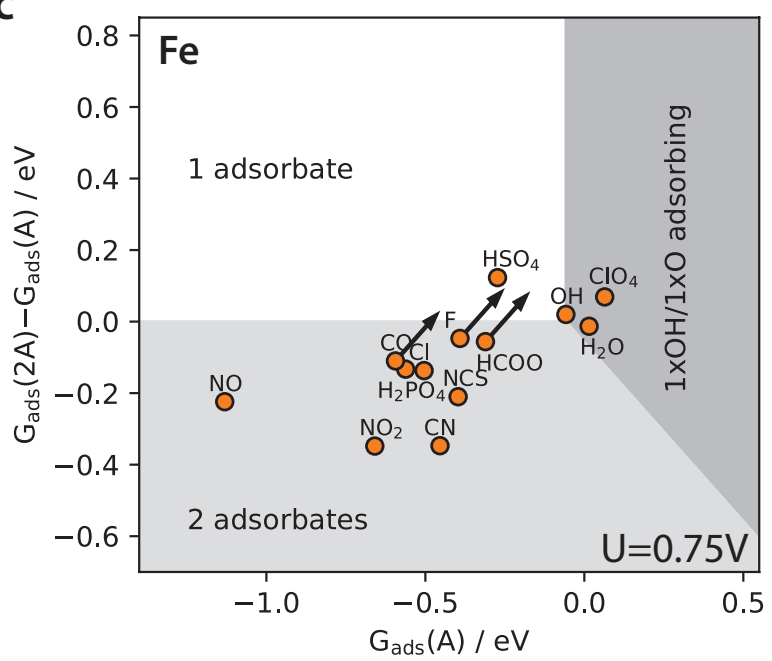

b

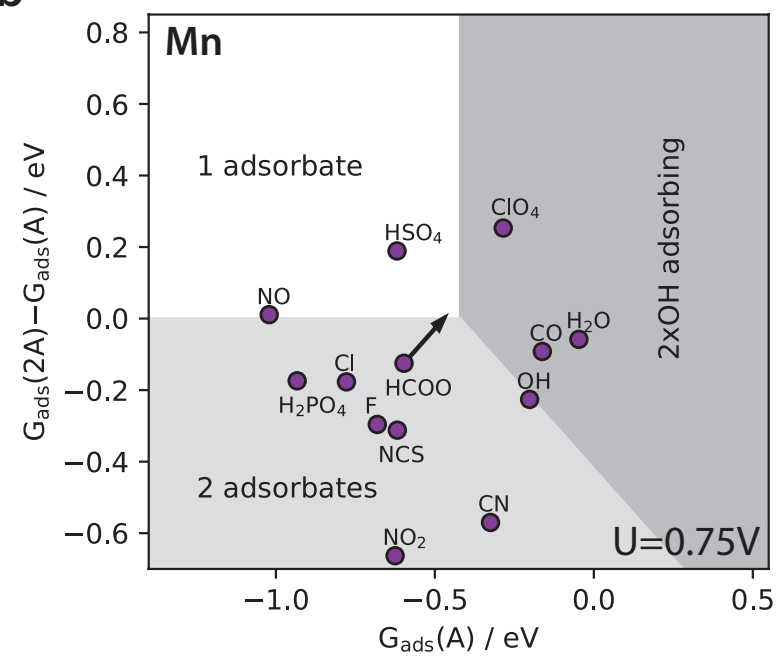

d

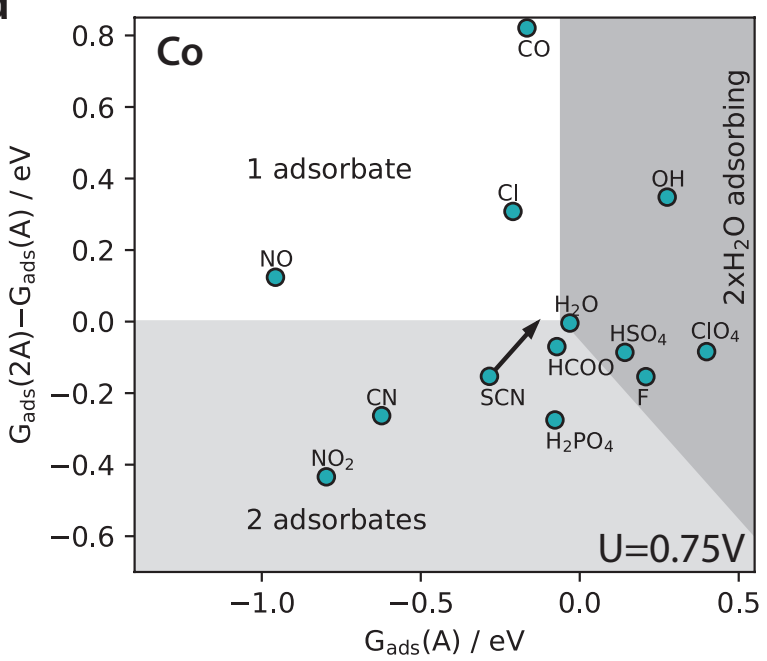

Figure 3: Differential adsorption free energy of the second adsorbate as a function of the adsorption free energy of the first adsorbate on the $\mathrm{M}-\mathrm{N}_{4}$ motives at $U=0.75 \mathrm{~V}$ with $\mathrm{M}=\mathrm{Cr}(\mathrm{a}), \mathrm{Mn}(\mathrm{b}), \mathrm{Fe}$ (c) and Co (d). Shaded regions indicate whether the outcome is adsorption of one adsorbate (white area), two adsorbates (light grey area) or if $\mathrm{H}_{2} \mathrm{O}, \mathrm{OH}^{-}$or $\mathrm{O}$ will adsorb instead (dark grey area). Arrows are drawn from some of the points that can be shifted to lie within the white area of the plot by a decrease in adsorbate concentration or partial pressure of less than three orders of magnitude. This direction also corresponds to a decrease in the potential for anionic adsorbates. 
gies (c.f. Section S9 of the ESI), show that binding of $\mathrm{HCOOH}, \mathrm{SO}_{4}{ }^{2-}$ and $\mathrm{HPO}_{4}{ }^{2-}$ is less favourable than binding of the corresponding monoanions at potentials below $0.75 \mathrm{~V}$ on any of the four metals. HCN has a positive free energy of adsorption on $\mathrm{Cr}, \mathrm{Mn}$ and $\mathrm{Co}$ but may adsorb instead of $\mathrm{CN}^{-}$on the Fe catalyst at potentials below $0.44 \mathrm{~V}$. Furthermore, adsorption of $2 \mathrm{H}_{3} \mathrm{PO}_{4}$ molecules is favoured over $\mathrm{H}_{2} \mathrm{PO}_{4}{ }^{-}$adsorption on both $\mathrm{Mn}$ and $\mathrm{Fe}$ at low potentials (below 0.15 and $0.42 \mathrm{~V}$, respectively). On $\mathrm{Co}, \mathrm{H}_{3} \mathrm{PO}_{4}$ adsorption is favoured up to a potential of $0.66 \mathrm{~V}$ and this combination has therefore been included in our further analysis of the influence of adsorbates on the ORR activity. In the case of $\mathrm{NO}$, a range of reductions and oxidations are possible in solution. Here, we compare only with the adsorbed $\mathrm{NO}_{2}$ via the process:

$$
\mathrm{NO}_{2}+2 \mathrm{H}^{+}+2 \mathrm{e}^{-} \longrightarrow \mathrm{NO}+\mathrm{H}_{2} \mathrm{O}
$$

The results show that NO is the more stable species at low potentials, in agreement with experimental reports suggesting that adsorbed $\mathrm{NO}$ can be created from $\mathrm{NO}_{2}$ on $\mathrm{Fe}-\mathrm{N}_{4}$ catalysts. ${ }^{37}$ At higher potentials, adsorption of $2 \mathrm{NO}_{2}$ becomes the most stable configuration; however, since adsorption of $2 \mathrm{NO}$ is not favourable on $\mathrm{Cr}$, $\mathrm{Mn}$ and $\mathrm{Co}$ the conversion of $2 \mathrm{NO}$ to $2 \mathrm{NO}_{2}$ might be kinetically hindered (c.f. Section S9 of the ESI for details).

\section{ORR activity}

Having identified the adsorption properties of all adsorbates, it is now investigated how the ORR activity is affected by the presence of an adsorbate on one side of the metal atom. Though the above results show that this situation is not possible for all combinations of metal and adsorbate, the results are calculated and included for completeness.

Since the active site is a single atom, the reaction is assumed to follow the associative pathway:

$$
\begin{array}{ll}
\mathrm{O}_{2}+\mathrm{H}^{+}+\mathrm{e}^{-}+{ }^{*} \longrightarrow{ }^{*} \mathrm{OOH} & \Delta \mathrm{G}_{1} \\
{ }^{*} \mathrm{OOH}+\mathrm{H}^{+}+\mathrm{e}^{-} \longrightarrow{ }^{*} \mathrm{O}+\mathrm{H}_{2} \mathrm{O} & \Delta \mathrm{G}_{2} \\
{ }^{*} \mathrm{O}+\mathrm{H}^{+}+\mathrm{e}^{-}+\longrightarrow{ }^{*} \mathrm{OH} & \Delta \mathrm{G}_{3} \\
{ }^{*} \mathrm{OH}+\mathrm{H}^{+}+\mathrm{e}^{-}+\longrightarrow{ }^{*}+\mathrm{H}_{2} \mathrm{O} & \Delta \mathrm{G}_{4}
\end{array}
$$

The reaction free energies $\left(\Delta \mathrm{G}_{1}-\Delta \mathrm{G}_{4}\right)$ are calculated from the adsorption energies of the different intermediates, which depend on the potential through Eqn. 2 (c.f. section S10 of the ESI). The limiting potential is defined as the highest potential at which all steps are downhill in free energy and can be found as:

$$
U_{L}=-\max \left\{\Delta \mathrm{G}_{1}, \Delta \mathrm{G}_{2}, \Delta \mathrm{G}_{3}, \Delta \mathrm{G}_{4}\right\} / e
$$

Here, an initial chemical step of $\mathrm{O}_{2}$ adsorption is not explicitly considered. Our calculations show that $\mathrm{O}_{2}$ adsorption on the bare metal sites is exothermic $(\Delta \mathrm{H}<0)$ and adsorption free energies range from $-0.57 \mathrm{eV}$ to $0.03 \mathrm{eV}$. The presence of an adsorbate on the back of $\mathrm{Fe}-\mathrm{N}_{4}$ can weaken $\mathrm{O}_{2}$ binding by up to $0.33 \mathrm{eV}$ (c.f. section $\mathrm{S} 7$ in the ESI). These results indicate that $\mathrm{O}_{2}$ adsorption has surmountable barriers at room temperature. Including proton coupled electron transfer of strongly adsorbed $\mathrm{O}_{2}$ as an electrochemical step on $\mathrm{Cr}-\mathrm{N}_{4}$ increases the reaction free energy of the first protonation step, however, the potential limiting step remains $\mathrm{OH}$ reduction to $\mathrm{H}_{2} \mathrm{O}$.

The adsorption free energy of the reaction intermediates ${ }^{*} \mathrm{OOH},{ }^{*} \mathrm{O}$ and ${ }^{*} \mathrm{OH}$, and thereby the limiting potential, is calculated for the catalysts without any other adsorbate and with the different adsorbates from Table 1 on one side. An example of the resulting energy diagrams for the ORR can be found in Section S6 of the ESI.

Plots of the limiting potential as a function of $\Delta \mathrm{G}_{\mathrm{ads}}(\mathrm{OH})$ for each of the four metals are shown in Figure $4 a-d$. Points corresponding to the adsorbatefree catalysts (marked as $\mathrm{M}^{*}$ in the plots) show that, for the bare catalyst, the reaction is limited by the ${ }^{*} \mathrm{OH}$ intermediate being bound too strongly $\left(\Delta \mathrm{G}_{4}\right)$ for $\mathrm{M}=\mathrm{Cr}, \mathrm{Mn}, \mathrm{Fe}$, while on Co the reaction is limited by the weak binding of the $* \mathrm{OOH}$ intermediate $\left(\Delta \mathrm{G}_{1}\right)$. Binding of an adsorbate on one side can be used to vary the binding energy of the ORR intermediates on the other side of the catalyst. The $\mathrm{M}-\mathrm{N}_{4}$ catalysts follow the scaling relation between the adsorption energies of the ${ }^{*} \mathrm{OH}$ and ${ }^{*} \mathrm{OOH}$ intermediates known from metal and oxide surfaces $\left(\Delta \mathrm{G}_{2}+\Delta \mathrm{G}_{3}=\right.$ $\Delta \mathrm{G}_{\mathrm{ads}}(\mathrm{OH})-\Delta \mathrm{G}_{\mathrm{ads}}(\mathrm{OOH}) \simeq-3.2 \mathrm{eV}$, indicated as black lines in Figure 4 4.53154 Since the overall change in free energy associated with the four-electron reduction of $\mathrm{O}_{2}$ to $\mathrm{H}_{2} \mathrm{O}$ is $4.92 \mathrm{eV}$, this relation implies that the best limiting potential that can be achieved is ca. $0.85 \mathrm{~V}$. In spite of the very different limiting potentials for the bare $\mathrm{M}-\mathrm{N}_{4}$ catalysts it is possible to get close to this value for all four metals by binding of an adsorbate on the back.

Figure 4 shows that most of the considered adsorbates will result in a weaker binding of ${ }^{*} \mathrm{OH}$ on the other side, which is advantageous on the $\mathrm{Cr}, \mathrm{Mn}$ and Fe catalysts where the ${ }^{*} \mathrm{OH}$ intermediate binds too 
a

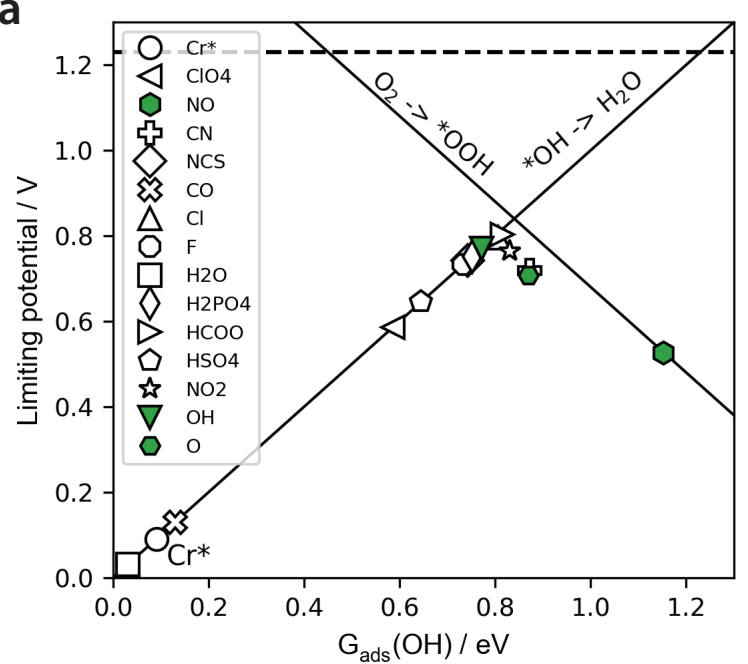

C

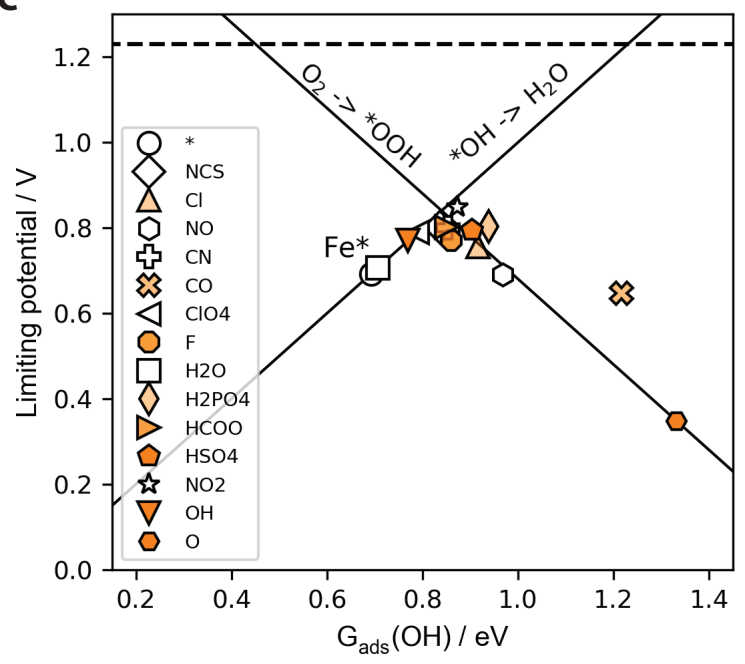

b

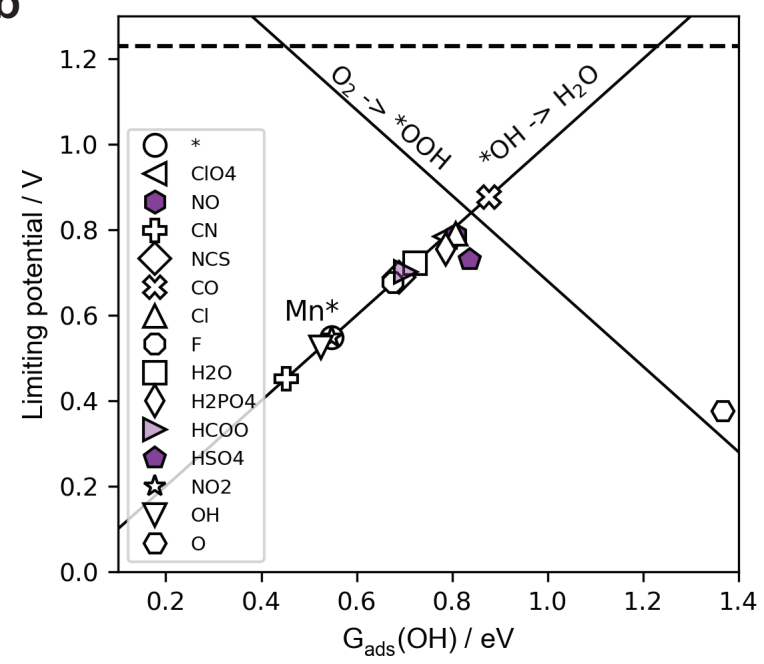

d

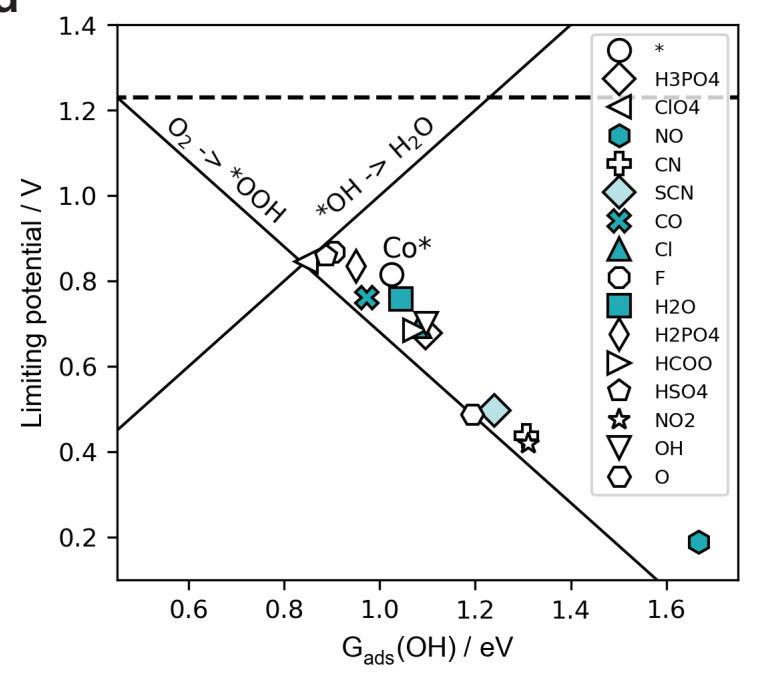

Figure 4: Limiting potential of the $\mathrm{M}-\mathrm{N}_{4}$ motifs with $\mathrm{M}=\mathrm{Cr}$ (a), $\mathrm{Mn}$ (b), Fe (c) and Co (d). Black full lines indicate the volcano defined by the scaling relations and the dashed line indicates the potential of an ideal catalyst in the absence of scaling relations. Adsorbates that adsorb on one side of the catalyst at the chosen conditions are marked by brightly coloured symbols, adsorbates that can be made to adsorb on one side only by tuning the concentration or partial pressure within three orders of magnitude are marked by palely coloured symbols and adsorbates that will not adsorb at all or will poison the catalyst are marked by white symbols. 
strongly on the bare catalyst. The magnitude of the change in ${ }^{*} \mathrm{OH}$ binding energy depends on the choice of metal, and is most significant for $\mathrm{Cr}$, where the bare catalyst has a limiting potential of just $0.09 \mathrm{eV}$. Adsorption of an anion or $\mathrm{NO}$ on the back results in a weakening of the ${ }^{*} \mathrm{OH}$ binding of more than $0.5 \mathrm{eV}$, while the shifts produced by $\mathrm{H}_{2} \mathrm{O}$ and $\mathrm{CO}$ are very small. This can be explained by the electronic structure of the $\mathrm{Cr}^{+2}$ ion which in the high-spin configuration has four unpaired $d$-electrons. If $\mathrm{OH}$ or another anion is the only adsorbate the resulting complex is square pyramidal and the $d$-orbitals are split such that the four $d$-electrons are in three different energy levels (c.f. Section S11 of the ESI for a schematic of the energy levels). The $d$-electron in the highest of these energy levels is transferred to ${ }^{*} \mathrm{OH}$, which is a relatively favourable process. However, if ${ }^{*} \mathrm{OH}$ is bound as the second adsorbate the configuration is octahedral, and there are only three remaining $d$-electrons which are placed in the three lowest lying $\left(t_{2 g}\right)$ orbitals. Transfering an unpaired electron from one of these orbitals to ${ }^{*} \mathrm{OH}$ is much less favourable, resulting in a lower energy gain when binding $\mathrm{OH}$ as the second anion. The difference is less significant for the other metals, since they can transfer paired electrons from the lower $t_{2 g} d$-orbitals or remaining electrons from the upper $e_{g} d$-orbitals when $\mathrm{OH}$ is the second adsorbate.

The limiting potentials of metal-adsorbate combinations for which adsorption on one side can be realised within the chosen range of concentrations are plotted in Figure 5 . While Figure 4 a shows that many anions in principle turn the relatively poor $\mathrm{Cr}-\mathrm{N}_{4}$ catalyst into a catalyst with a competitive limiting potential, most of them bind too strongly, resulting in poisoning of the catalyst. Thus, $\mathrm{NO}$ and $\mathrm{OH}^{-}$are the only adsorbates that adsorb on one side only, leading to theoretical limiting potential for ORR of 0.53 and $0.77 \mathrm{~V}$, respectively. In practice, the limiting potential for $\mathrm{OH}^{-}$can not be reached, since $\mathrm{OH}^{-}$is oxidized to $\mathrm{O}$ at a potential of $0.74 \mathrm{~V}$, at which point ORR can no longer proceed on the other side due to weak binding of the ${ }^{*} \mathrm{OOH}$ intermediate. On Mn, we predict that $\mathrm{NO}, \mathrm{HSO}_{4}{ }^{-}$and $\mathrm{HCOO}^{-}$at a reduced concentration should all improve the catalytic performance, resulting in limiting potentials in the range $0.70 \mathrm{~V}-0.79 \mathrm{~V}$. On Fe there are also several adsorbates that result in limiting potentials in the range $0.65 \mathrm{eV}-0.80 \mathrm{eV}$. $\mathrm{HSO}_{4}{ }^{-}$ and $\mathrm{OH}^{-}$are predicted to adsorb on one side under the chosen conditions, while the concentration of $\mathrm{F}^{-}$, $\mathrm{Cl}^{-}, \mathrm{HCOO}^{-}, \mathrm{H}_{2} \mathrm{PO}_{4}^{-}$and $\mathrm{CO}$ must be reduced to avoid poisoning. As is the case for $\mathrm{Cr}$, the limiting potential with $\mathrm{OH}^{-}$can not be reached, since $\mathrm{OH}^{-}$is oxidized to $\mathrm{O}$ at a potential of $0.75 \mathrm{~V}$, and the limiting potential for ORR with $\mathrm{O}$ adsorbed on the back is just $0.35 \mathrm{~V}$. Finally, for the Co catalyst, $\mathrm{Cl}^{-}, \mathrm{CO}, \mathrm{NO}$ and $\mathrm{SCN}^{-}$can be made to adsorb on one side only with limiting potentials of $0.69 \mathrm{~V}, 0.76 \mathrm{~V}, 0.19 \mathrm{~V}$ and $0.50 \mathrm{~V}$, respectively. However, in the presence of a non-adsorbing acid, the Co catalyst will have $\mathrm{H}_{2} \mathrm{O}$ adsorbed on both sides of the metal atom with a binding energy for the second water molecule of only $-0.01 \mathrm{eV}$. At room temperature, one of the water molecules will therefore be desorbed a significant fraction of the time, allowing ORR to proceed at a high limiting potential of $0.76 \mathrm{~V}$ on the other side. The best possible limiting potential can thus be achieved either with $\mathrm{CO}$ adsorbed on the back or in the presence of one of the non-adsorbing acids: $\mathrm{H}_{2} \mathrm{SO}_{4}, \mathrm{HF}$ or $\mathrm{HClO}_{4}$.

It is of interest to compare our results with experiments reported in the litterature, keeping in mind the variation in catalyst preparation and poisoning procedures across these studies. An experiment comparing the activities of $\mathrm{M}-\mathrm{N} / \mathrm{C}$ catalysts with $\mathrm{M}=\mathrm{Mn}$, $\mathrm{Fe}$, Co found that they followed the ordering $\mathrm{Fe}>$ Co $>$ Mn with the halfwave potentials of the three metals differing by $0.08 \mathrm{eV}$. To match this observation with theoretical calculations they suggested that a ligand in the form of spontaneously evolved $\mathrm{OH}$ must be adsorbed on one side of the metal atom. ${ }^{26}$ Since the experiment was performed in $0.5 \mathrm{M} \mathrm{H}_{2} \mathrm{SO}_{4}$, our calculations suggest that the ligand would be $\mathrm{HSO}_{4}$ on $\mathrm{Fe}$ and $\mathrm{Mn}$ and $\mathrm{H}_{2} \mathrm{O}$ on $\mathrm{Co}$, resulting in limiting potentials of $0.73,0.79$ and $0.76 \mathrm{~V}$ for $\mathrm{Mn}, \mathrm{Fe}$ and $\mathrm{Co}$, respectively. These numbers match the experimentally observed trends and also correspond well with the variation in the measured halfwave potentials. Most other poisoning experiments of $\mathrm{M}-\mathrm{N} / \mathrm{C}$ catalysts have been performed on $\mathrm{Fe}$ based catalysts. The activity of a commercially available Fe-N/C catalyst has been investigated experimentally in various solvents, and the results were found to compare well with DFT calculations. ${ }^{32] 33}$ The studies found increased kinetic currents in $0.25 \mathrm{M} \mathrm{H}_{3} \mathrm{PO}_{4}$ and $0.5 \mathrm{M} \mathrm{HCOOH}$ compared with a reference solution of $\mathrm{HClO}_{4}$, while the performance was unchanged in $0.25 \mathrm{M} \mathrm{H}_{2} \mathrm{SO}_{4}$, and reduced in $0.25 \mathrm{M} \mathrm{HCl}$. Our calculations show that $\mathrm{HClO}_{4}$ does not adsorb on the Fe catalyst at the relevant potentials, and that ORR in the reference solution instead would proceed with $\mathrm{OH}^{-}$adsorbed on one side up to a potential of $0.75 \mathrm{~V}$, at which point $\mathrm{OH}^{-}$is oxidized to $\mathrm{O}$. In agreement with the experimental results, a slightly better limiting potential of $0.80 \mathrm{~V}$ 
is calculated for both $\mathrm{HCOO}^{-}$and $\mathrm{H}_{2} \mathrm{PO}_{4}{ }^{-}$but our calculations suggest that the concentration of $\mathrm{H}_{3} \mathrm{PO}_{4}$ should be reduced below the $0.25 \mathrm{M}$ used in the experiment to avoid poisoning. For $\mathrm{HSO}_{4}{ }^{-}$adsorption on one side and a limiting potential of $0.79 \mathrm{~V}$ is likewise predicted but no improvement in the performance was observed experimentally. ${ }^{\sqrt{32}}$ Finally, the reduced performance in $\mathrm{HCl}$ is consistent with our calculations, which predict poisoning by $\mathrm{Cl}^{-}$. Two other experimental studies concerning the effect of halide ions have however shown less significant effects. ${ }^{34135}$ A possible explanation for this could be that lower concentrations of the halide were employed in these studies, which, according to our calculations for $\mathrm{F}^{-}$and $\mathrm{Cl}^{-}$, could result in only one halide atom binding. The experimental results for $\mathrm{CO}$ are likewise inconclusive with some studies showing no effect while others report a partial decrease in the performance. $\frac{34|36| 55 \mid}{\text { Our calculations }}$ suggest that $\mathrm{CO}$ would adsorb on one or both sides of the $\mathrm{Fe}-\mathrm{N}_{4}$ motif depending on the partial pressure, and this would lead to a reduced limiting potential or poisoning, respectively. Previous calculations have shown that $\mathrm{CO}$ adsorption is only favoured over $\mathrm{O}_{2}$ adsorption on some types of $\mathrm{FeN}_{x} \mathrm{C}_{y}$ sites, which could explain why some catalysts were found to be unaffected by $\mathrm{CO} \cdot{ }^{36}$ Furthermore, the adsorption of $\mathrm{CO}$ on the Mn-based catalyst is calculated to be weaker than on the Fe-based catalyst, in agreement with experiments in ref. 56 comparing the two metals. Finally, the strong poisoning effect observed experimentally for $\mathrm{CN}^{-}$is consistent with the strong binding calculated here. $\stackrel{35 \mid 40}{ }$ Overall, our calculations thus compare well with the available results for M-N/C catalysts.

\section{Conclusion}

We have investigated how various adsorbates affect the catalytic properties of ORR catalysts based on the $\mathrm{M}-\mathrm{N}_{4}$ motif with $\mathrm{M}=\mathrm{Cr}, \mathrm{Mn}, \mathrm{Fe}$, Co. From the calculated adsorption energies it is possible to identify adsorbates that will poison the catalyst under typical operating conditions and adsorbates that will not influence the catalyst because they do not adsorb. In addition, our results reveal a small number of adsorbates that will adsorb on one side of the $\mathrm{M}-\mathrm{N}_{4}$ motif only, thereby changing the limiting potential for ORR on the remaining site. Interestingly, in spite of the differences in limiting potential for the bare $\mathrm{M}-\mathrm{N}_{4}$ motifs, it is possible to obtain limiting potentials close to the optimum value within the scaling relations for all four metals by introducing an appropriate adsorbate.

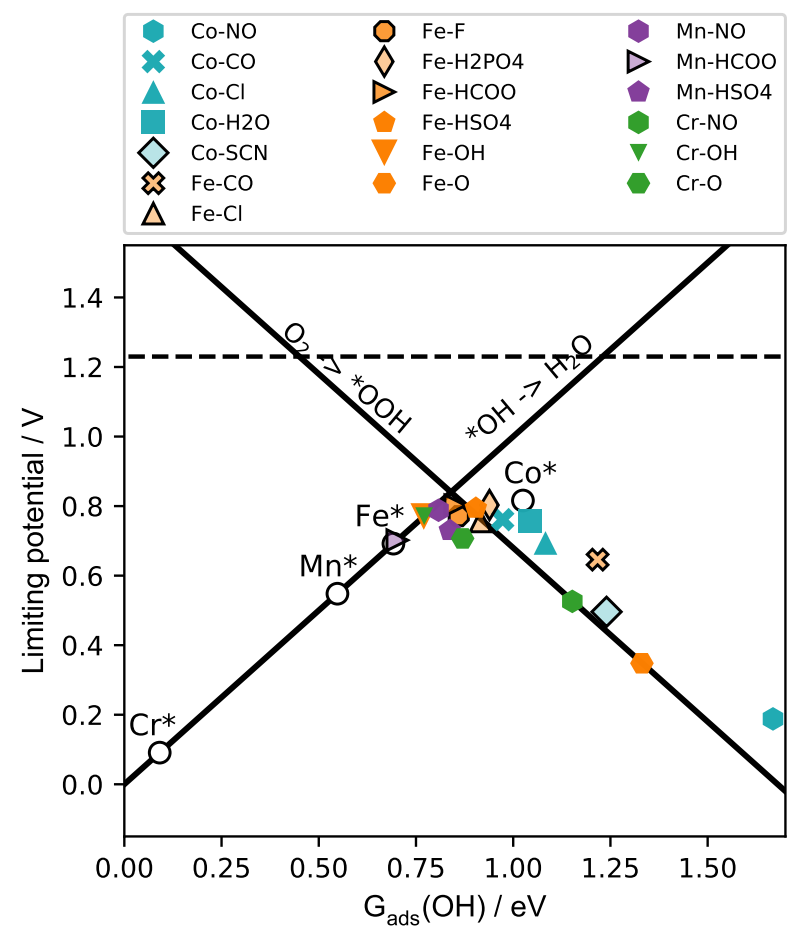

Figure 5: Limiting potential for $\mathrm{M}-\mathrm{N}_{4}$ motives with adsorbed anions that are possible to realise according to our calculations, either with the settings chosen here (bright colors, no outline) or by tuning the concentration between $1 \mathrm{M}$ and $1 \mathrm{mM}$ for acids and the partial pressure between 1 bar and 1 mbar for gases (pale colors, black outline). Combinations on Co are coloured in blue colours, Mn in purple, $\mathrm{Cr}$ in green and $\mathrm{Fe}$ in orange. Black full lines indicate the volcano defined by the scaling relations and the dashed line indicates the equilibrium potential of the four electron ORR. The activity of the bare $\mathrm{M}-\mathrm{N}_{4}$ motifs are plotted in white for reference. 
This illustrates that the chemical environment in the fuel cell is an important parameter to control in order to optimize the efficiency of $\mathrm{M}-\mathrm{N} / \mathrm{C}$ catalysts. Our results compare well with experimental results which have mostly been performed on $\mathrm{Fe}-\mathrm{N} / \mathrm{C}$ catalysts, and it would be interesting to see this comparison extended to other metals.

\section{Acknowledgements}

This work was supported by the Velux Foundations through the research center V-Sustain (grant number 9455).

\section{Supplementary Information}

Electronic Supplementary Information: Further computational details, thermochemical data, tables of adsorption energies etc. are available as pdf. DFT optimised structures are available as ASE databases from DOI: 10.5281/zenodo.3383988 (link activated upon acceptance).

Keywords: Density functional calculations, Electrochemistry, Fuel cells, Oxygen reduction reaction, Nonprecious catalyst

\section{References}

[1] G. Crabtree, M. Dresselhaus, MRS Bulletin 2008, 33, 421-428.

[2] Z. Chen, D. Higgins, A. Yu, L. Zhang, J. Zhang, Energy Environ. Sci. 2011, 4, 3167-3192.

[3] M. Shao, Q. Chang, J.-P. Dodelet, R. Chenitz, Chemical Reviews 2016, 116, 3594-3657.

[4] W. Xia, A. Mahmood, Z. Liang, R. Zou, S. Guo, Angewandte Chemie International Edition 2016, 55, 2650-2676.

[5] R. Jasinski, Nature 1964, 201, 1212-1213.

[6] V. Bagotzky, M. Tarasevich, K. Radyushkina, O. Levina, S. Andrusyova, Journal of Power Sources 1978, 2, $233-240$.

[7] J. Li, F. Jaouen, Current Opinion in Electrochemistry 2018, 9, $198-206$.

[8] D. Singh, J. Tian, K. Mamtani, J. King, J. T. Miller, U. S. Ozkan, Journal of Catalysis 2014, $317,30-43$.
[9] J. A. Varnell, E. C. M. Tse, C. E. Schulz, T. T. Fister, R. T. Haasch, J. Timoshenko, A. I. Frenkel, A. A. Gewirth, Nature Communications 2016, \%, 12582 .

[10] W.-J. Jiang, L. Gu, L. Li, Y. Zhang, X. Zhang, L.-J. Zhang, J.-Q. Wang, J.-S. Hu, Z. Wei, L.-J. Wan, Journal of the American Chemical Society 2016, 138, 3570-3578.

[11] H. Alt, H. Binder, G. Sandstede, Journal of Catalysis 1973, 28, 8 - 19 .

[12] U. I. Kramm, J. Herranz, N. Larouche, T. M. Arruda, M. Lefévre, F. Jaouen, P. Bogdanoff, S. Fiechter, I. Abs-Wurmbach, S. Mukerjee, J.P. Dodelet, Phys. Chem. Chem. Phys. 2012, 14, 11673-11688.

[13] U. I. Kramm, M. Lefévre, N. Larouche, D. Schmeisser, J.-P. Dodelet, Journal of the American Chemical Society 2014, 136, 978-985.

[14] M. Lefévre, J. P. Dodelet, P. Bertrand, The Journal of Physical Chemistry B 2005, 109, 1671816724.

[15] H. T. Chung, D. A. Cullen, D. Higgins, B. T. Sneed, E. F. Holby, K. L. More, P. Zelenay, Science 2017, 35\%, 479-484.

[16] A. Zitolo, V. Goellner, V. Armel, M.-T. Sougrati, T. Mineva, L. Stievano, E. Fonda, F. Jaouen, Nature Materials 2015, 14, 937-942.

[17] C. E. Szakacs, M. Lefévre, U. I. Kramm, J.-P. Dodelet, F. Vidal, Phys. Chem. Chem. Phys. 2014, 16, 13654-13661.

[18] E. F. Holby, P. Zelenay, Nano Energy 2016, 29, $54-64$.

[19] S. Kattel, P. Atanassov, B. Kiefer, The Journal of Physical Chemistry C 2012, 116, 8161-8166.

[20] R. Borup, J. Meyers, B. Pivovar, Y. S. Kim, R. Mukundan, N. Garland, D. Myers, M. Wilson, F. Garzon, D. Wood, P. Zelenay, K. More, K. Stroh, T. Zawodzinski, J. Boncella, J. E. McGrath, M. Inaba, K. Miyatake, M. Hori, K. Ota, Z. Ogumi, S. Miyata, A. Nishikata, Z. Siroma, Y. Uchimoto, K. Yasuda, K.-i. Kimijima, N. Iwashita, Chemical Reviews 2007, 10\%, 3904-3951. 
[21] M. Santos, D. Miwa, S. Machado, Electrochemistry Communications 2000, 2, $692-696$.

[22] V. Bagotzky, Y. Vassilyev, J. Weber, J. Pirtskhalava, Journal of Electroanalytical Chemistry and Interfacial Electrochemistry 1970, 27, 31 46.

[23] Q. Jia, N. Ramaswamy, H. Hafiz, U. Tylus, K. Strickland, G. Wu, B. Barbiellini, A. Bansil, E. F. Holby, P. Zelenay, S. Mukerjee, ACS Nano 2015, 9, 12496-12505.

[24] E. F. Holby, C. D. Taylor, Scientific Reports 2015, 5,9286 .

[25] A. B. Anderson, E. F. Holby, The Journal of Physical Chemistry C 2019, 123, 18398-18409.

[26] U. Martinez, E. F. Holby, S. K. Babu, K. Artyushkova, L. Lin, S. Choudhury, G. M. Purdy, P. Zelenay, Journal of The Electrochemical Society 2019, 166, F3136-F3142.

[27] M. Busch, N. B. Halck, U. I. Kramm, S. Siahrostami, P. Krtil, J. Rossmeisl, Nano Energy 2016, 29, 126 - 135.

[28] Y. Han, Y. Wang, R. Xu, W. Chen, L. Zheng, A. Han, Y. Zhu, J. Zhang, H. Zhang, J. Luo, C. Chen, Q. Peng, D. Wang, Y. Li, Energy Environ. Sci. 2018, 11, 2348-2352.

[29] Y. Wang, H. Yuan, Y. Li, Z. Chen, Nanoscale 2015, 7, 11633-11641.

[30] G. Zhu, F. Liu, Y. Wang, Z. Wei, W. Wang, Phys. Chem. Chem. Phys. 2019, 21, 12826-12836.

[31] Y. Lin, P. Liu, E. Velasco, G. Yao, Z. Tian, L. Zhang, L. Chen, Advanced Materials 2019, 31, 1808193.

[32] K. Holst-Olesen, M. Reda, H. A. Hansen, T. Vegge, M. Arenz, ACS Catalysis 2018, 8, 71047112 .

[33] K. Holst-Olesen, L. Silvioli, J. Rossmeisl, M. Arenz, ACS Catalysis 2019, 9, 3082-3089.

[34] Q. Wang, Z.-Y. Zhou, Y.-J. Lai, Y. You, J.-G. Liu, X.-L. Wu, E. Terefe, C. Chen, L. Song, M. Rauf, N. Tian, S.-G. Sun, Journal of the American Chemical Society 2014, 136, 10882-10885.
[35] M. S. Thorum, J. M. Hankett, A. A. Gewirth, The Journal of Physical Chemistry Letters 2011, 2, 295-298.

[36] Q. Zhang, K. Mamtani, D. Jain, U. Ozkan, A. Asthagiri, The Journal of Physical Chemistry C 2016, 120, 15173-15184.

[37] D. Malko, A. Kucernak, T. Lopes, Journal of the American Chemical Society 2016, 138, 1605616068.

[38] D. Singh, K. Mamtani, C. R. Bruening, J. T. Miller, U. S. Ozkan, ACS Catalysis 2014, 4, 34543462 .

[39] Q. Li, G. Wu, D. A. Cullen, K. L. More, N. H. Mack, H. T. Chung, P. Zelenay, ACS Catalysis 2014, 4, 3193-3200.

[40] U. Tylus, Q. Jia, K. Strickland, N. Ramaswamy, A. Serov, P. Atanassov, S. Mukerjee, The Journal of Physical Chemistry C 2014, 118, 8999-9008.

[41] G. Zhang, X. Yang, M. Dubois, M. Herraiz, R. Chenitz, M. LefÃ̂lvre, M. Cherif, F. Vidal, V. P. Glibin, S. Sun, J.-P. Dodelet, Energy Environ. Sci. 2019,--.

[42] W. Kohn, L. J. Sham, Phys. Rev. 1965, 140, A1133-A1138.

[43] G. Kresse, J. Hafner, Phys. Rev. B 1993, 47, $558-561$.

[44] P. E. Blöchl, Phys. Rev. B 1994, 50, 1795317979.

[45] A. H. Larsen, J. J. Mortensen, J. Blomqvist, I. E. Castelli, R. Christensen, M. Dułak, J. Friis, M. N. Groves, B. Hammer, C. Hargus, E. D. Hermes, P. C. Jennings, P. B. Jensen, J. Kermode, J. R. Kitchin, E. L. Kolsbjerg, J. Kubal, K. Kaasbjerg, S. Lysgaard, J. B. Maronsson, T. Maxson, T. Olsen, L. Pastewka, A. Peterson, C. Rostgaard, J. Schiøtz, O. Schütt, M. Strange, K. S. Thygesen, T. Vegge, L. Vilhelmsen, M. Walter, Z. Zeng, K. W. Jacobsen, Journal of Physics: Condensed Matter 2017, 29, 273002.

[46] J. Wellendorff, K. T. Lundgaard, A. Møgelhøj, V. Petzold, D. D. Landis, J. K. Nørskov, T. Bligaard, K. W. Jacobsen, Phys. Rev. B 2012, 85, 235149 . 
[47] F. Calle-Vallejo, J. I. Martínez, J. Rossmeisl, Phys. Chem. Chem. Phys. 2011, 13, 15639-15643.

[48] K. Mathew, R. Sundararaman, K. LetchworthWeaver, T. A. Arias, R. G. Hennig, The Journal of Chemical Physics 2014, 140, 084106.

[49] K. Mathew, R. G. Hennig, arXiv:1601.03346 2016.

[50] J. K. Nørskov, J. Rossmeisl, A. Logadottir, L. Lindqvist, J. R. Kitchin, T. Bligaard, H. Jónsson, The Journal of Physical Chemistry B 2004, 108, 17886-17892.

[51] R. Christensen, H. A. Hansen, C. F. Dickens, J. K. Nørskov, T. Vegge, The Journal of Physical Chemistry C 2016, 120, 24910-24916.

[52] R. Christensen, H. A. Hansen, T. Vegge, Catal. Sci. Technol. 2015, 5, 4946-4949.

[53] I. C. Man, H.-Y. Su, F. Calle-Vallejo, H. A. Hansen, J. I. Martínez, N. G. Inoglu, J. Kitchin, T. F. Jaramillo, J. K. Nørskov, J. Rossmeisl, ChemCatChem 2011, 3, 1159-1165.

[54] V. Viswanathan, H. A. Hansen, J. Rossmeisl, J. K. Nørskov, ACS Catalysis 2012, 2, 1654-1660.

[55] L. Birry, J. H. Zagal, J.-P. Dodelet, Electrochemistry Communications 2010, 12, 628 - 631 .

[56] N. R. Sahraie, U. I. Kramm, J. Steinberg, Y. Zhang, A. Thomas, T. Reier, J.-P. Paraknowitsch, P. Strasser, Nature Communications 2015, 6,8618 . 


\section{TOC graphics}

The adsorption of anions and impurities from the electrolyte on non-precious $\mathrm{M}-\mathrm{N}_{4}$ catalysts $(\mathrm{M}=\mathrm{Cr}, \mathrm{Mn}$, $\mathrm{Fe}, \mathrm{Co})$ for the oxygen reduction reaction (ORR) is investigated using density functional theory calculations. Some combinations of metal and adsorbate lead to an improvement in the limiting potential for ORR.

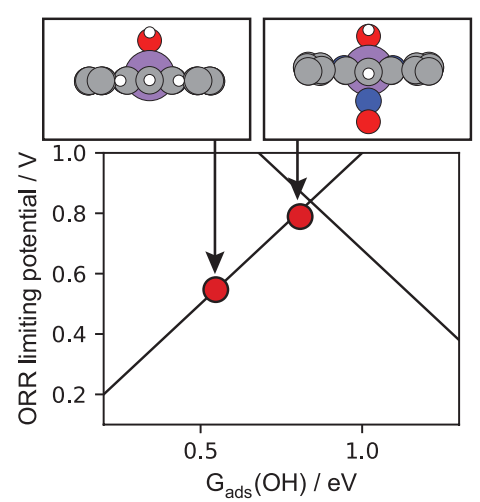

